\title{
PENGARUH KEMAMPUAN BERPIKIR KRITIK DAN KONSEP DIRI TERHADAP PRESTASI BELAJAR MATEMATIKA
}

\author{
DONA KATARINA \\ dona.katrin@gmail.com \\ Universitas Indraprasta PGRI Jakarta \\ Jl. Nangka 58. Tanjung Barat (TB Simatupang) Jagakarsa, Jakarta Selatan \\ http://www.unindra.ac.id
}

\begin{abstract}
Abstrak. Pengaruh langsung kemampuan berpikir kritik terhadap konsep diri siswa, mengetahui pengaruh langsung konsep diri siswa terhadap prestasi belajar matematika serta untuk mengetahui pengaruh tidak langsung kemampuan berpikir kritik terhadap prestasi belajar matematika melalui konsep diri siswa.Analisis data dengan menggunakan metode statistik deskriptif dan teknik uji persyaratan analisis data. Hasil penelitian menunjukkan: (1). terdapat pengaruh langsung yang signifikan kemampuan berpikir kritik dan konsep diri terhadap prestasi belajar matematika Siswa. (2). terdapat pengaruh langsung yang signifikan kemampuan berpikir kritik terhadap prestasi belajar matematika. (3). terdapat pengaruh langsung yang signifikan konsep diri terhadap prestasi belajar matematika.(4).terdapat pengaruh tidak langsung yang tidak signifikan kemampuan berpikir kritik terhadap prestasi belajar matematika melalui konsep diri.
\end{abstract}

Kata kunci: kemampuan berpikir kritik, konsep diri, prestasi belajar matematika siswa

\begin{abstract}
The direct effect of the ability to think criticism of the concept of self-esteem, self-concept directly determine the effect of students' mathematics achievement and to determine the effect of indirect criticism of the ability to think mathematics achievement through student self-concept. Data analysis using descriptive statistical methods and testing techniques of data analysis requirements. The results showed: (1). there is a significant direct influence thinking skills of criticism and self-concept of the student mathematics achievement. (2). there is a significant direct influence thinking skills critique of mathematics achievement. (3). there is a significant direct effect on the achievement of self-concept study mathematics. (4).terdapat indirect effect is not significant ability to think criticism of mathematics achievement through self-concept.
\end{abstract}

Keywords: Criticism Thinking Skills, Self-Concept, Achievement Math Students

\section{PENDAHULUAN}

Pada dasarnya manusia diberikan kemampuan untuk dapat mengenal diri dan dapat berpikir secara kritik. Sehingga dapat memahami mengenal diri sendiri atau ide mengenai diri sendiri (Sifert dan Hoffnung, 1994). Oleh sebab itu kemampuan mengenal diri sangat penting karena apabila seseorang sudah mengenal dirinya maka seseorang tersebut dapat mengembangkan dan meningkatkan kemampuannya dalam melakukan sesuatu. Kemampuan dalam berpikir yang masuk akal dan reflektif yang terfokus untuk memutuskan apa yang mesti dipercaya atau dilakukan dalam segala hal (Norris dan Erniss, 1989). Oleh Sebab itu dalam mengembangkan dan meningkatkan kemampuan berpikir secara kritik kita perlu adanya kemampuan untuk dapat menganalisis, memahami akan segala sesuatu yang berhubungan atas kemampuan diri sendiri dalam memahami dan menganalisis permasalahan yang dihadapi.

Selanjutnya dalam mengarahkan dan mengembangkan serta meningkatkan konsep diri yang ada pada masing-masing individu khususnya peserta didik dapat dilakukan 
diantaranya: mengembangkan kemampuan dan bakat yang dimiliki oleh masing-masing peserta didik sehingga peserta didik dapat mengetahui seberapa besar kemampuan diri yang dimilikinya. Kemudian guru juga dapat memberikan kepada peserta didik suatu permasalahan untuk mengetahui kemampuan diri berupa kekurangan dan kelebihan yang dimiliki oleh peserta didik sehingga peserta didik dapat percaya diri untuk mengembangkan kemampuan dirinya tersebut.

Dari kemampuan dasar yang telah dimiliki tersebut oleh masing-masing individu khususnya peserta didik diharapkan kemampuan tersebut dapat meningkatkanprestasi belajar dan dapat mengembangkan kemampuan yang telah dimiliki oleh peserta didik kearah yang lebih baik yakni peningkatan prestasi hasil belajar.

Kemampuan mengenal diri atau mengkonsep diri serta berpikir secara kritik sangatlah dibutuhkan dalam mengembangkan kemampuan menganalisis, memecahkan masalah, mensintesis dan menyimpulkan permasalahan yang dihadapi dalam kehidupan sehari-hari serta menguji atau mengkritisi untuk memperoleh jawaban atas permasalahan yang dihadapinya. Kemampuan dasar inilah sangat dibutuhkan dalam meningkatkan prestasi hasil belajar khususnya dibidang Matematika. Mata pelajaran Matematika merupakan ratunya ilmu, sebab semua cabang ilmu pasti memerlukan perhitungan. Matematika merupakan suatu pelajaran yang tersusun secara beraturan, logis dan berjenjang dari paling mudah hingga rumit.

Adapun tujuan pengajaran matematika disekolah berdasarkan standar kurikulum yang berbasis kompetensi agar siswa memperoleh kemampuan berhitung dan berpikir logis serta memahami suatu konsep. Melalui pengajaran siswa mampu mengembangkan kompetensi untuk berpikir logis. Oleh karena itu dalam mempelajari matematika siswa diharapkan dapat berpikir secara logis, kritis dan sistematis yang dalam aplikasinya dapat dilihat melalui kehidupan dan cara berpikir kritis siswa secara nyata. Hal ini menunjukkan bahwa seberapa besar pemahaman wawasan materi matematika dapat diterapkan siswa dimasyarakat. Karena Menurut Haryono "kesadaran berpikir logis yang tampil pada diri seseorang atau masyarakat adalah refleksi dari wawasannya."

Kemudian untuk mengetahui peningkatan prestasi belajar matematika perlu adanya penilaian. Penilaian adalah upaya atau tindakan untuk mengetahui sejauh mana tujuan yang telah ditetapkan itu tercapai atau tidak. Dengan kata lain, penilaian berfungsi sebagai alat untuk mengetahui keberhasilan proses dan hasil belajar siswa (Sri Esti, 2006: 110). Tes prestasi belajar dilakukan untuk mengetahui prestasi yang telah dicapai oleh sesuatu bentuk pengajaran. Prestasi belajar yang dicoba diungkapkan melalui tes yang menitik beratkan perhatiannya pada prestasi pengajaran secara keseluruhan pada akhir pertengahan semester atau akhir semester. Sebagai tes yang menitikberatkan perhatiaannya pada prestasi yang telah dicapai selama belajar, tes prestasi belajar terkait erat dengan apa yang telah diajarkan. Kaitannya terutama pada isi tes yang harus mencerminkan isi pengajaran secara nyata telah diselenggarakan (Sri Esti, 2006: 412)

Tes prestasi belajar merupakan butir tes yang digunakan untuk mengetahui prestasi belajar siswa setelah mengikuti kegiatan belajar mengajar. Tes prestasi belajar meliputi tes prestasi belajar produk, tes prestasi belajar psikomotorik berupa keterampilan melaksanakan eksperimen.

Tes prestasi belajar dibuat mengacu pada kompetensi dasar yang ingin dicapai, dijabarkan kedalam indikator pencapaian prestasi belajar dan disusun berdasarkan kisikisi penulisan butir soal lengkap dengan kunci jawabannya serta lembar observasi penilaian psikomotorik kinerja siswa (Sumarna, 2007:8) 


\section{TINJAUAN PUSTAKA}

Dari kesemua pendapat diatas dapat disimpulkan bahwa belajar adalah proses kegiatan seseorang dalam merubah perilaku di dalam dirinya melalui beberapa proses dan setiap prosesnya mengalami perubahan secara bertahap baik dipengaruhi faktor internal maupun faktor eksternal yang didasari oleh pengalaman individu tersebut dalam kegiatan pembelajaran.

Prestasi merupakan kecakapan atau hasil kongkrit yang dapat dicapai seseorang pada waktu tertentu atau periode tertentu dari proses kegiatan pembelajaran. Prestasi Belajar adalah suatu nilai yang menunjukkan hasil yang tertinggi dalam belajar yang ingin dicapai menurut kemampuan siswa dalam mengerjakan sesuatu pada saat tertentu. Prestasi belajar siswa ditentukan oleh dua faktor yaitu intern dan ekstern. Faktor intern merupakan faktor-faktor yang berasal atau bersumber dari siswa itu sendiri, sedangkan faktor eksternal merupakan faktor yang berasal atau bersumber dari luar peserta didik.

Faktor intern meliputi prasyarat belajar, yakni pengetahuan yang sudah dimiliki oleh siswanya sebelum mengikuti pelajaran berikutnya, keterampilan belajar yang dimiliki oleh siswa meliputi cara-cara yang berkaitan dengan mata pelajaran, mengerjakan tugas, mambaca buku, belajar kelompok, mempersiapkan ujian, menindaklanjuti hasil ujian dan mencari sumber belajar, kondisi siswa yang meliputi kesehatan, kecerdasan, sikap, cita-cita dan hubungannya dengan oranglain. Faktor ekstern antara lain meliputi proses belajar mengajar, sarana belajar yang dimiliki,lingkungan belajar dan kondisi sosial ekonomi keluarga.

Menurut para ahli, matematika berasal dari bahasa latin "mathematika" yang mulanya diambil dari bahasa yunani "Mathematike" yang berarti mempelajari. Perkataan itu mempunyai asal kata mathema yang berarti pengetahuan atau ilmu. Kata mathematike berhubungan pula dengan kata lainnya yang hampir sama yaitu mathein atau mathenein yang artinya belajar. Jadi berdasarkan asal katanya maka matematika berarti ilmu pengetahuan yang didapat dengan berpikir. Adapun tujuan pengajaran matematika disekolah adalah: agar siswa mampu memiliki pengetahuan berpikir logis untuk memahami dan menjelaskan proses dalam kehidupan dimasyarakat serta menemukan dan menumbuhkan jati diri bangsa ditengah-tengah masyarakat dunia.

Konsep diri terbentuk melalui proses belajar sejak masa pertumbuhan seorang manusia dari kecil hingga dewasa. Sedangkan harga diri timbul dari penilaian seseorang akan diri dan lingkungan pun memberikan pengaruh terhadap diri. Lingkungan, pengalaman dan pola asuh orang tua turut memberikan pengaruh yang signifikan terhadap konsep diri dan harga diri yang akan terbentuk.

Kemampuan berpikir kritik pada setiap individu harus berasal dari pemikiran yang masuk akal dan efektif yang terfokus untuk memusatkan apa yang mesti dipercaya atau dilakukan (Norris dan Ennis dalam buku Alec Fisher, 2008:4)

Berikut merupakan keterampilan-keterampilan berpikir yang dipandang sebagai landasan untuk berpikir kritis diantaranya: 1) Mengenal masalah, 2) Menemukan caracara yang dapat dipakai untuk menangani masalah-masalah yang dihadapi, 3) Mengumpulkan dan menyususn informasi yang diperlukan, 4) Mengenal Asumsi-asumsi dan nilai-nilai yang tidak dinyatakan, 5) Memahami dan menggunakan bahasa yang tepat, jelas, dan khas, 6) Menganalisis data, 7) Menilai fakta dang mengevaluasi pertanyaanpertanyaan, 8) Mengenal adanya hubungan yang logis antara masalah-masalah, 9) Menarik kesimpulan-kesimpulan dan kesamaan-kesamaan yang diperlukan, 10) Menguji kesamaan-kesamaan dan kesimpulan-kesimpulan yang diambil seseorang, 11) Menyusun kembali pola-pola keyakinan seseorang berdasarkan pengalaman yang lebih luas, dan 12) Membuat penilaian yang tepat tentang hal-hal dan kualitas-kualitas tertentu dalam kehidupan sehari-hari (Gleser dalam kutipan Alec Fisher, 2008:7). 
Berdasarkan uraian tersebut dapat disimpulkan bahwa kemampuan berpikir kritik merupakan proses intelektual yang dengan aktif dan terampil mengkonseptualisasi, menerapkan, menganalisis, mensintesis dan mengevaluasi informasi yang dikumpulkan atau dihasilkan dari pengamatan, pengalaman, refleksi, penalaran, atau komunikasi untuk memandu keyakinan dan tindakan.

\section{METODE}

Adapun penelitian dilakukan selama kurang lebih 4 bulan dari bulan Maret sampai Juni 2015, dengan mengambil sampelsebanyak 90 sampel secara random. Sampeladalah bagian dari populasi yang diambil hanya sebagian atau mewakili dari populasi yang diteliti (Arikunto, 2002).

Lebih lanjut penelitian ini menggunakan metode survei, pemberian kuesioner dan melakukan tes berupa pemberian soal soal matematika terhadap siswa-siswa di kelas VII SMP Negeri 42, SMP Negeri 34 dan SMP Negeri 23 se-kecamatan Pademangan, Jakarta Utara. Perlakuan terhadap variabel-variabel yang diteliti yaitu kemampuan berpikir kritis (X1) dan konsep diri (X2) terhadap hasil belajar matematika (Y).

Metode ini digunakan untuk mengemukakan ada tidaknya pengaruh antara variabel kemampuan berpikir kritis (X1) dengan konsep diri (X2) terhadap hasil belajar matematika (Y). Dengan cara perhitungan analisis jalur, dengan pembagian 2 variabel, yaitu: (1). Variabel yang mempengaruhi (Eksogen) dan (2) Variabel yang dipengaruhi (Endogen). Variabel yang mempengaruhi (eksogen) terdiri dari: (a) Variabel kemampuan berpikir kritik (X1) merupakan variabel eksogen bagi konsep diri siswa (X2) dan prestasi belajar Matematika (Y) serta (b).Kemampuan berpikir kritis (X1) merupakan variabel eksogen bagi prestasi belajar Matematika (Y). Sedangkan untuk variabel yang dipengaruhi (endogen) terdiri dari: (a) Kemampuan berpikir kritik (X1) merupakan variabel eksogen bagi konsep diri siswa (X2) dan prestasi belajar Matematika (Y). (b) Kemampuan berpikir kritis (X1) merupakan variabel eksogen bagi prestasi belajar Matematika (Y).

Untuk lebih jelas dapat dilihat dari desain penelitian dalam gambar 1.

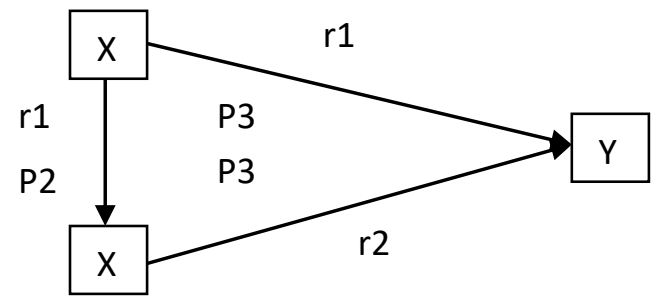

Gambar 1. Hubungan Kemampuan berpikir kritik dan konsep diri terhadap prestasi belajar matematika (Konstelasi Masukan)

Keterangan:

$\mathrm{X} 1=$ Kemampuan berpikir kritik

$\mathrm{X} 2=$ Konsep diri

$\mathrm{Y}=$ Prestasi belajar Matematika 
HASIL DAN PEMBAHASAN

Analisis Variabel Prestasi Belajar Siswa

Tabel 1. Hasil Perhitungan Deskriptif Variabel Prestasi Belajar

\begin{tabular}{llr}
\hline \multicolumn{1}{c}{ N } & Valid & $\mathbf{9 0}$ \\
\hline Mean & Missing & 0 \\
Std. Error Of Mean & & 63.71 \\
Median & & 1.189 \\
Mode & & 64.00 \\
Std. Deviation & & 64 \\
Variance & & 11.29 \\
Range & & 127.219 \\
Minimum & 51 \\
Maximum & & 35 \\
Sum & & 86 \\
\hline
\end{tabular}

Analisis Deskriptif Variabel Kemampuan Berpikir Kritik

Tabel 2. Hasil Perhitungan Deskriptif Variabel Kemampuan Berpikir Kritik

\begin{tabular}{llr}
\hline \multicolumn{1}{c}{ N } & Valid & $\mathbf{9 0}$ \\
\hline & Missing & 0 \\
Mean & & 49.78 \\
Std. Error Of Mean & & .553 \\
Median & & 50.00 \\
Mode & & 50 \\
Std. Deviation & 5.244 \\
Variance & & 27.501 \\
Range & & 26 \\
Minimum & 34 \\
Maximum & & 60 \\
Sum & & 4480 \\
\hline
\end{tabular}

Analisis Deskriptif Variabel Konsep Diri

Tabel 3. Hasil Perhitungan Deskriptif Variabel Konsep Diri

\begin{tabular}{llr}
\hline N & Valid & $\mathbf{9 0}$ \\
\hline & Missing & 0 \\
Mean & & 111.14 \\
Std. Error Of Mean & & .569 \\
Median & & 112.00 \\
Mode & & 115 \\
Std. Deviation & 5.402 \\
Variance & 29.181 \\
Range & 27 \\
Minimum & 98 \\
Maximum & 125 \\
Sum & & 10003 \\
\hline
\end{tabular}




\section{Uji Hipotesis Penelitian}

Untuk melukiskan dan menguji hubungan antar variabel penelitian, peneliti menggunakan Analisis Jalur (Path Analysis). Untuk hal tersebut peneliti menyusun model hubungan antar variabel berdasarkan kerangka berpikir yang dikembangkan. Untuk keperluan tersebut peneliti menyusun diagram jalur sebagai berikut:

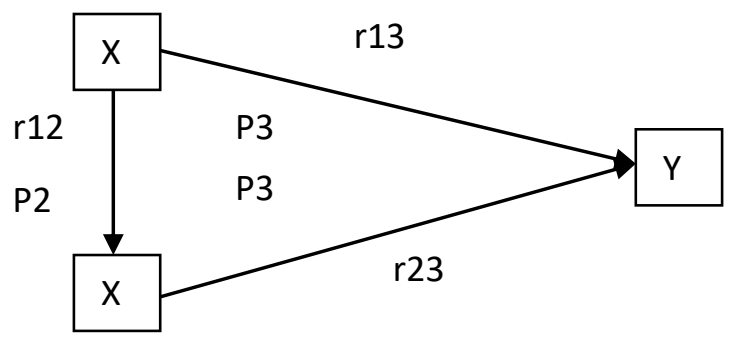

Gambar 2. Diagram Analisis jalur

Dalam melakukan Analisis Pengujian Hipotesis Penelitian, Peneliti menggunakan Analisis Koefisien Korelasi sederhana antar 2 ( dua) variabel untuk menentukan koefisien korelasi dengan bantuan program SPSS 21.0. Adapun Hasilnya sebagai berikut:

Tabel 4. Hasil Perhitungan Korelasi

\begin{tabular}{|c|c|c|c|c|}
\hline & & $\begin{array}{l}\text { Kemampuan } \\
\text { Berpikir } \\
\text { Kritik } \\
\end{array}$ & Konsep Diri & $\begin{array}{l}\text { Prestasi } \\
\text { Belajar }\end{array}$ \\
\hline \multirow{4}{*}{$\begin{array}{l}\text { Kemampuan } \\
\text { Berpikir } \\
\text { Kritik }\end{array}$} & Pearson & 1 & $.224 *$ & $.709 * *$ \\
\hline & Correlation & & & \\
\hline & Sig. (2-tailed) & & .034 & .000 \\
\hline & $\mathrm{N}$ & 90 & 90 & 90 \\
\hline \multirow[t]{4}{*}{ Konsep Diri } & Pearson & $.224 *$ & 1 & $.384 * *$ \\
\hline & Correlation & & & \\
\hline & Sig. (2-tailed) & .034 & & .000 \\
\hline & $\mathrm{N}$ & 90 & 90 & 90 \\
\hline Prestasi & Pearson & $.709 * *$ & $.384 * *$ & 1 \\
\hline \multirow[t]{3}{*}{ Belajar } & Correlation & & & \\
\hline & Sig. (2-tailed) & .000 & .000 & \\
\hline & $\mathrm{N}$ & 90 & 90 & 90 \\
\hline \multicolumn{5}{|c|}{ *Correlation is significant at the 0.05 level (2-tailed) } \\
\hline
\end{tabular}

Tabel 5. Rangkuman Hasil Analisis Koefisien Korelasi

\begin{tabular}{|c|c|c|}
\hline Hubungan Antar Variabel $r_{i j}$ & Korelasi & Nilai \\
\hline $\begin{array}{l}\text { Kemampuan berpikir kritik }\left(\mathrm{X}_{1}\right) \text { dengan } \\
\text { Prestasi Belajar }\end{array}$ & $\mathrm{r}_{13}$ & 0.709 \\
\hline Konsep Diri $\left(\mathrm{X}_{2}\right)$ dengan Prestasi Belajar $\left(\mathrm{X}_{3}\right)$ & $\mathrm{r}_{23}$ & 0.384 \\
\hline $\begin{array}{l}\text { Kemampuan Berpikir Kritik }\left(\mathrm{X}_{1}\right) \text { dengan } \\
\text { Konsep Diri }\left(\mathrm{X}_{2}\right)\end{array}$ & $\mathrm{r}_{12}$ & 0.224 \\
\hline
\end{tabular}


Tabel 6. Hasil Perhitungan Koefisien Jalur Kemampuan Berpikir Kritik (X1), Konsep Diri Siswa (X2) terhadap Prestasi Belajar Matematika (X3)

\begin{tabular}{|c|c|c|c|c|c|}
\hline \multirow[t]{2}{*}{ Model } & \multicolumn{2}{|c|}{$\begin{array}{l}\text { Unstandardized } \\
\text { Coefficients }\end{array}$} & $\begin{array}{l}\text { Standardized } \\
\text { Coefficients }\end{array}$ & $\mathbf{t}$ & Sig \\
\hline & B & Std.Error & Beta & & \\
\hline 1 (Constant) & -61.496 & 17.082 & & -3.600 & .001 \\
\hline $\begin{array}{l}\text { Kemampuan } \\
\text { Berpikir Kritik }\end{array}$ & 1.411 & .158 & .656 & 8.947 & .000 \\
\hline Konsep Diri & .495 & .153 & .237 & 3.232 & .002 \\
\hline
\end{tabular}

a. Dependent Variabel: Prestasi Belajar

Tabel 7. Hasil Perhitungan Koefisien Jalur Kemampuan Berpikir Kritik (X1) terhadap Konsep Diri Siswa (X2)

Coefficients $^{a}$

\begin{tabular}{|c|c|c|c|c|c|}
\hline \multirow[t]{2}{*}{ Model } & \multicolumn{2}{|c|}{$\begin{array}{l}\text { Unstandardized } \\
\text { Coefficients }\end{array}$} & $\begin{array}{l}\text { Standardized } \\
\text { Coefficients }\end{array}$ & $\mathbf{t}$ & Sig \\
\hline & B & Std.Error & Beta & & \\
\hline $1($ Constant $)$ & 99.656 & 5.356 & & 18.606 & .000 \\
\hline $\begin{array}{l}\text { Kemampuan } \\
\text { Berpikir Kritik }\end{array}$ & .231 & .107 & .224 & 2.157 & .034 \\
\hline
\end{tabular}

b. Dependent Variabel: Konsep Diri

Dari hasil perhitungan koefisien jalur melalui aplikasi SPSS ini terlihat bahwa koefisien jalur untuk nilai p21, p31 dan p32 adalah lebih besar dari 0.05 , untuk nilai p21 $=0.224, \mathrm{p} 31=0.656$ dan $\mathrm{p} 32=0.237$. hal ini dapat membuktikan bahwa diagram jalur yang disusun dapat diterima.

Sehingga bila disusun diagram koefisien korelasi dan koefisien jalurnya sebagai berikut:

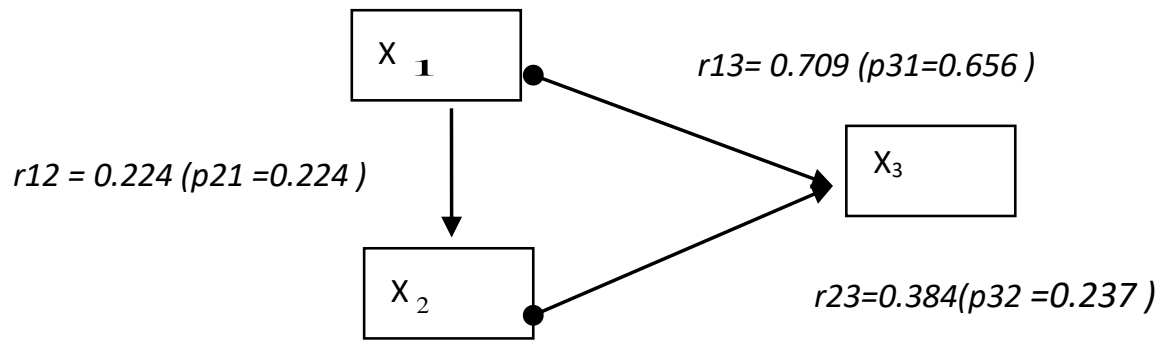

Gambar 3. Diagram Koefisien Korelasi dan Koefisien Jalur

Dari koefisien jalur yang diperoleh angka yang signifikan (diatas 0.05). Hal ini membuktikan bahwa diagram jalur yang disusun dapat diterima, sehingga:

1. Terdapat pengaruh langsung $X_{1}$ terhadap $X_{3}$, dan juga pengaruh tidak langsung $X_{1}$ terhadap $\mathrm{X}_{3}$ melalui $\mathrm{X}_{2}$

2. Terdapat pengaruh langsung $X_{1}$ terhadap $X_{2}$

3. Terdapat pengaruh langsung $X_{2}$ terhadap $X_{3}$

\section{Pengujian Hipotesis Penelitian}

Pengujian Hipotesis Kesatu

$\mathrm{H} 0: \mathrm{P}_{31}=0$ tidak terdapat pengaruh langsung kemampuan berpikir (X1) kritik terhadap prestasi belajar matematika (X3) 
$\mathrm{H} 1: \mathrm{P}_{31} \neq 0$ terdapat pengaruh langsung yang signifikan kemampuan berpikir kritik (X1) terhadap prestasi belajar matematika (X3)

Dari tabel 6. Hasil Perhitungan Koefisien Jalur Kemampuan Berpikir Kritik (X1), Konsep Diri Siswa (X2) terhadap Prestasi Belajar Matematika (X3) terlihat bahwa nilai $t$ hitung untuk kemampuan berpikir krititik (X1) terhadap prestasi belajar sebesar $(\mathrm{X} 3)=8.947$. Untuk $\alpha=0,05$ dan $\mathrm{dk}=\mathrm{n}-\mathrm{k}-1=90-2-1=87$ pada uji dua pihak diperoleh nilai $\mathrm{t}_{\text {tabel }}$ $=\mathrm{t}_{\mathrm{t}}=1.987$. Karena nilai $\mathrm{t}_{\text {hitung }} 8.947>\mathrm{t}_{\text {tabel }} 1,987$ maka H0 ditolak dan H1 diterima maka disimpulkan terdapat pengaruh langsung yang signifikan Kemampuan Berpikir Kritikterhadap Prestasi Belajar Matematika.

Pengujian Hipotesis Kedua

$\mathrm{H} 0: \mathrm{P}_{32}=$ 0tidak terdapat pengaruh langsung konsep diri (X2) terhadap prestasi belajar matematika (X3)

$\mathrm{H} 1: \mathrm{P}_{32} \neq 0$ terdapat pengaruh langsung yang signifikan konsep diri (X2) terhadap prestasi belajar matematika (X3)

Dari tabel 6. Hasil Perhitungan Koefisien Jalur Kemampuan Berpikir Kritik (X1), Konsep Diri Siswa (X2) terhadap Prestasi Belajar Matematika (X3) terlihat bahwa nilai $\mathrm{t}$ hitung untuk Konsep diri (X2) terhadap prestasi belajar sebesar $(\mathrm{X} 3)=3.232$. Untuk $\alpha=0,05$ dan $\mathrm{dk}=\mathrm{n}-\mathrm{k}-1=90-2-1=87$ pada uji dua pihak diperoleh nilai $\mathrm{t}_{\text {tabel }}=\mathrm{t}_{\mathrm{t}}=1.987$. Karena nilai $t_{\text {hitung }} 3.232>\mathrm{t}_{\text {tabel }}$ 1,987 maka $\mathrm{H} 0$ ditolak dan $\mathrm{H} 1$ diterima maka disimpulkan terdapat pengaruh langsung yang signifikan Konsep Diriterhadap Prestasi Belajar Matematika

Pengujian Hipotesis Ketiga

H0: $\mathrm{P}_{21}=0$ tidak terdapat pengaruh langsung kemampuan berpikir (X1) kritik terhadap konsep diri (X2)

$\mathrm{H} 1: \mathrm{P}_{21} \neq 0$ terdapat pengaruh langsung yang signifikan kemampuan berpikir kritik (X1) terhadap konsep diri (X2)

Berdasarkan analisis jalur diketahui bahwa koefisien jalur variabel Kemampuan berpikir kritik terhadap konsep diri siswa, maka diperoleh nilait hitung $_{=}($Supardi, 2013). Dari Tabel 7. Hasil Perhitungan Koefisien Jalur Kemampuan Berpikir Kritik (X1)terhadap Konsep Diri Siswa (X2) terlihat bahwa nilai $t_{\text {hitung }}$ untuk kemampuan berpikir kritik (X1) terhadap konsep diri $(\mathrm{X} 2)=2.157$. Untuk $\alpha=0,05 \mathrm{dan} \mathrm{dk}=\mathrm{n}-\mathrm{k}-1=90-2-1=87$ pada uji dua pihak diperoleh nilai $t_{\text {tabel }}=t_{t}=1.987$. Karena nilai $t_{\text {hitung }} 2.157>t_{\text {tabel }} 1,987$ maka H0 ditolak dan H1 diterima maka disimpulkan terdapat pengaruh langsung yang signifikan Konsep Diri Siswa terhadap Prestasi belajar Matematika.

Pengujian Hipotesis Keempat

H0: $\mathrm{P}_{321}=0$ tidak terdapat pengaruh langsung yang signifikan kemampuan berpikir kritik melalui konsep diri terhadap prestasi belajar matematika

$\mathrm{H} 1: \mathrm{P}_{321} \neq 0$ 0terdapat pengaruh langsung kemampuan berpikir kritik melalui konsep diri terhadap prestasi belajar matematika

Untuk menguji koefisien Jalur secara tidak langsung antara X1 ke Y melalui X2 yaitu dengan rumus:

$$
\mathrm{P}_{321}=\mathrm{P}_{21} \mathrm{X} \mathrm{P}_{32}=0.224 \mathrm{X} 0.237=0.053
$$


Untuk pengujian hipotesis berdasarkan dari tabel 6. Hasil Perhitungan Koefisien Jalur Kemampuan Berpikir Kritik (X1), Konsep Diri (X2) terhadap Prestasi Belajar Matematika (X3) dan tabel 7. Hasil Perhitungan Koefisien Jalur Kemampuan Berpikir Kritik (X1)terhadap Konsep Diri Siswa (X2), diketahui $S_{21}{ }^{2}=0.107^{2}=0.011$ dan $S_{32}{ }^{2}=$ $0.153^{2}=0.023$, sehingga didapat simpangan baku gabungan:

$$
\begin{aligned}
& S_{g}=\sqrt{(\mathrm{n} 21-1) S_{2} \underline{1}^{2}+(\mathrm{n} 32-1) \underline{S}_{32} \underline{\underline{2}}} \\
& \mathrm{n}_{21}+\mathrm{n}_{32}-2 \\
& S_{g}=\sqrt{\frac{(90-1)(0.107)^{2}+(90-1)(0.153)^{2}}{90+90-2}} \\
& S_{g}=\sqrt{(89)(0.107)^{2}+(89)(0.153)^{2}} \\
& 178 \\
& S_{g}=\sqrt{\underline{(89)(0.011)+(89)(0.023)}} \\
& 178 \\
& S_{g}=\sqrt{\underline{0.979+2.047}} \\
& 178 \\
& \mathrm{~S}_{\mathrm{g}}=\sqrt{0.017}=0.130
\end{aligned}
$$

Maka nilai $\mathrm{t}_{\mathrm{h}}\left(\right.$ Supardi, 2012) yaitu: $\mathrm{t}_{\mathrm{h}}=\underline{\mathrm{p}}_{321}=\underline{0.053}=0.408 \mathrm{~S}_{\mathrm{g}} 0.130$

Untuk $\mathrm{a}=0.05$ dan $\mathrm{dk}=\mathrm{n}-\mathrm{k}-1=90-2-1=87$ pada uji dua pihak diperoleh $\mathrm{t}_{\text {tabel }}=\mathrm{t}_{\mathrm{t}}$ 1.987. karena nilai $\mathrm{t}_{\text {hitung }}<\mathrm{t}_{\text {tabel }}=0.408<1.987$, maka $\mathrm{H} 0$ diterima dan $\mathrm{H} 1$ ditolak sehingga disimpulkan tidak terdapat pengaruh yang signifikan kemampuan berpikir kritik terhadap prestasi belajar matematika melalui konsep diri siswa.

Berdasarkan analisis jalur diketahui bahwa koefisien jalur variabel kemampuan berpikir kritik terhadap prestasi belajar matematika melalui konsep dirip321 $=\mathrm{p} 21 \mathrm{X} \mathrm{p} 32=0.224$ $\mathrm{X} 0.237=0.053$. jika dibandingkan dengan nilai $\mathrm{p} 31$ maka nilai $\mathrm{p} 321=0.053<\mathrm{p} 31=$ 0.656. Hal ini menginterprestasikan bahwa varaibel intervening tidak berpengaruh secara signifikan terhadap prestasi belajar. 


\section{Interprestasi Hasil Penelitian \\ Pengaruh Langsung Kemampuan Berpikir Kritik Terhadap Prestasi Belajar Matematika Siswa}

Dari hasil perhitungan regresi linear uji hipotesis dengan bantuan aplikasi SPSS versi 21.0 ternyata ada hubungan secara langsung kemampuan berpikir kritik demgan prestasi belajar. Ini terlihat dari $\mathrm{t}_{\text {hitung }}>\mathrm{t}$ tabel $=8.947>1.987$ dengan taraf signifikan $5 \%$ ataua $=0.05$, sehingga membuktikan bahwa terdapat pengaruh langsung kemampuan berpikir kritik terhadap hasil prestasi belajar matematika siswa. Besarnya pengaruh kemampuan berpikir kritik terhadap prestasi belajar adalah: $\mathrm{KD}=\mathrm{p}_{31}{ }^{2} \mathrm{X} 100 \%=0.656^{2} \mathrm{X}$ $100 \%=43.03 \%$, sisanya sebesar $56.97 \%$ dipengaruhi oleh faktor-faktor lain diluar kemampuan berpikir kritik.

Jadi dari hasil penelitian yang telah diuji melalui penelitian survey ini disimpulkan bahwa kemampuan berpikir kritik berpengaruh langsung terhadap prestasi belajar matematika Siswa. Oleh sebab ituperlu menjadi perhatian bagi para pendidik atau tenaga kependidikan agar perlu adanya peningkatan pembelajaran yang menggunakan kemampuan penganalisisan dan pengevaluasian atau pengujian kebenaran atas permasalahan yang dihadapi berupa kesimpulan antara teori dengan kenyataan terhadap permasalah yang dihadapi pada pembelajaran sehingga membuat peserta didik dapat mengembangkan kemampuan berlogika atau kemampuan berpikir kritik dalam pembelajaran.

\section{Pengaruh Langsung Konsep Diri Terhadap Prestasi Belajar Matematika}

Dari hasil perhitungan regresi linear uji hipotesis dengan bantuan aplikasi SPSS versi 21.0 ternyata ada hubungan secara langsung konsep diri dengan prestasi belajar. Ini terlihat dari $\mathrm{t}$ hitung $>\mathrm{t}$ tabel $=3.232>1.987$ dengan taraf signifikan $5 \%$ ataua $=0.05$, sehingga membuktikan bahwa konsep diri secara langsung mempengaruhi peningkatan prestasi belajar matematika. Temuan penelitian menunjukkan bahwa terdapat korelasi yang cukup signifikan konsep diri dengan prestasi belajar matematika siswa. Hal ini ditunjukkan oleh angka koefisien korelasir $_{23}=0.384$ dan Sig $<0.05$ pada analisis korelasi. $\mathrm{KD}=\mathrm{p}_{23}{ }^{2} \mathrm{X} 100 \%=0.237^{2} \times 100 \%=0.056 \times 100 \%,=5.61 \%$ dan sisanya sebesar $94 \%$ dipengaruhi oleh faktor-faktor lain diluar konsep diri.

\section{Pengaruh Langsung Kemampuan Berpikir Terhadap Konsep Diri}

Temuan dalam penelitian ini menunjukkan bahwa terdapat korelasi yang signifikan antara kemampuan berpikir kritik dengan konsep diri hal ini ditunjukkan oleh angka koefisien korelasi sebesar $=0.224$ dan sig lebih kecil dari 0.05 pada analisis korelasi.

Terdapat pengaruh langsung yang signifikan kemampuan berpikir kritik terhadap konsep diri. hal ini ditunjukkan oleh angka koefisen jalur sebesar $=0.224$ lebih besar dari 0.05 dan hasil uji $-\mathrm{t}$ dimana nilai $\mathrm{t}$ hitung $=2.157>\mathrm{t}$ tabel $=1.987$. Besarnya pengaruh kemampuan berpikir kritik terhadap konsep diri adalah sama dengan $\mathrm{KD}=\mathrm{P}_{12}{ }^{2} \mathrm{X} 100 \%=$ $0.224^{2} \times 100 \%=5.01 \%$ sedangkan sisanya sebesar $94.99 \%$ dipengaruhi oleh faktor lainnya. Sehingga dapat disimpulkan berdasarkan uji penelitian survei, yakni apabila seseorang tersebut mampu mengkonsep dirinya atas permasalahan yang dihadapi maka secara langsung kemampuan berpikir kritik akan timbul sejalan dengan pencarian jawaban atau penyelesaian permasalahan yang dihadapi.

\section{Pengaruh Kemampuan Berpikir Kritik Terhadap Prestasi Belajar Melalui Konsep Diri}

Berdasarkan analisis jalur diketahui bahwa koefisien jalur variabel kemampuan berpikir kritik terhadap prestasi belajar matematika melalui konsep dirip321 =p21 X p32= 
$0.224 \times 0.237=0.053$. jika dibandingkan dengan nilai $\mathrm{p} 31$ maka nilai $\mathrm{p} 321=0.053<\mathrm{p} 31$ $=0.656$. Hal ini menginterprestasikan bahwa variabel intervening tidak berpengaruh secara signifikan terhadap prestasi belajar.

Dan dari hasil uji hipotesis penelitian dengan mencari nilai t hitung untuk pengaruh kemampuan berpikir kritik terhadap prestasi belajar melalui konsep diri diperoleh nilai $\mathrm{t}$ hitung $=0.408<\mathrm{t}_{\text {tabel }}=1.987$ dengan taraf signifikan $=0.05$ sehingga membuktikan bahwa terdapat pengaruh tidak langsung yang tidak signifikan terhadap prestasi belajar melalui konsep diri. Artinya kemampuan berpikir kritik mempengaruhi prestasi belajar secara tidak langsung melalui konsep diri, sehingga apabila seseorang tersebut mampu meningkatkan pengkonsepan dirinya maka secara langsung kemampuan berpikir kritik pun dapat memberikan pengaruh yang besar secara positif sehingga dapat meningkatkan prestasi belajar matematika.

Temuan penelitian menunjukkan bahwa tidak terdapat pengaruh tidak langsung dan signifikan kemampuan berpikir kritik terhadap prestasi belajar melalui konsep diri, hal ini dapat terlihat dari besarnya pengaruh tidak langsung yakni $\mathrm{p} 321=\mathrm{p}_{21} \mathrm{X} \mathrm{p}_{32} \mathrm{X} 100 \%$ $=0.224 \times 0.237 \times 100 \%=0.053=5.3 \%$. sedangkan sisanya sebesar $94.7 \%$ dipengaruhi oleh faktor lain.

\section{PENUTUP}

\section{Simpulan}

Dari hasil penelitian maka didapat simpulan sebagai berikut:

a. Terdapat pengaruh langsung yang signifikan kemampuan berpikir kritikterhadap prestasi belajar matematika,maka diimplikasikan semakin baik kemampuan berpikir kritik yang dimiliki oleh siswa maka semakin baik pula prestasi belajarnya

b. Terdapat pengaruh langsung yang signifikan Konsep diri terhadap prestasi belajar matematika,

c. Terdapat pengaruh langsung yang signifikan kemampuan berpikir kritik terhadap konsep diri, maka dapat diimplikasikan semakin baik kemampuan berpikir kritik dan konsep diri siswa maka semakin baik pula hasil prestasi belajar yang dicapai

d. Terdapat pengaruh tidak langsung yang tidak signifikan kemampuan berpikir kritik siswa terhadap prestasi belajar matematika melalui konsep diri.

e. Lingkungan yang baik, didikan guru dan orangtua yang dapat membuat anak semakin percaya diri dan berkemampuan berpikir kritik merupakan bentuk dari motivasi yang bertujuan untuk peningkatan prestasi belajar matematika.

\section{Saran}

a. Bagi pendidik dan tenaga kependidikan khususnya para guru agar setiap kegiatan pembelajaran diharapkan diberikan permasalahan yang menarik sehingga para peserta didik tertantang untuk dapat meningkatkan kemampuan berpikir kritik sehingga kemampuan tersebut dapat meningkatkan prestasi belajar matematika menjadi lebih baik.

b. Bagi para orangtua, pendidik dan tenaga kependidikan diharapkan dapat terus meningkatkan pemberian motivasi dan arahan kedepan bagi para peserta didik sehingga peserta didik memiliki kemauan atau kemampuan mengkonsep diri menjadi lebih baik.

c. Perlu diadakan penelitian lanjutan untuk sampel dan variabel lebih besar, untuk mengetahui seberapa besar dampak kemampuan berpikir kritik dan konsep diri terhadap prestasi belajar matematika 


\section{DAFTAR PUSTAKA}

Arikunto, Suharsimi. 2001. Prosedur Penelitian Suatu Pendekatan Praktek. Jakarta: Rineka Cipta.

Aunurrahman. 2009. Belajar dan Pembelajaran, Belajar dan Pembelajaran. Bandung: CV Alfa Beta.

Brow Company Publisher. Konsep Diri Positif dan Konsep Diri Negatif. di download 24 Februari 2012

Edy. Kemampuan Berpikir Kritis, Kreatif, dan Pro Aktif. di Download 5 Oktober 2012, dari http://sigmalearning.wordpress.com

Fisher, Alec. 2009. Berpikir Kritis sebuah Pengantar. Jakarta: Erlangga.

Oemar, Hamalik. 2001. Proses Belajar Mengajar. Jakarta: Bumi Aksara. 2004. Kurikulum Pembelajaran. Jakarta: PT. Bumi Aksara.

Purwanto, Ngalim. 2007. Psikologi Pendidikan. Bandung: PT. Remaja Rosdakarya. Rosdakarya.

Prasetyo, Bambang. 2006. Metode Penelitian Kuantatif Teori dan Aplikasi. Jakarta: PT. Raja Grafindo Persada.

Sudjana, Nana. 2009. Penilaian Hasil Proses Belajar Mengajar. Bandung: PT. Remaja Rosdakarya.

Slameto, 2010. Belajar dan Faktor-faktor yang mempengaruhi. Jakarta: PT. Rineka Cipta.

Supardi. 2012. Aplikasi Statistik dalam Penelitan. Jakarta: PT. Ufuk Publishing House.

Surapranata, Sumarna. 2004. Analisis, Validitas, Reliabilitas, dan Interprestasi. Bandung. 